\title{
ADDITIONS SOME SOIL MICROBES AFFECTING AVAILABILITY OF HEAVY METALS CONCENTRATION UNDER DIFFERENT SOIL TILLAGE SYSTEMS
}

\author{
Abo-Habaga, M. M.;* Ghazy, M.** and W. S. Atwa***
}

\section{ABSTRACT}

The main object of this study is to investigate the influence of adding different soil microorganisms under different tillage systems such as conventional, intensive and conservation tillage on concentration of some heavy metals and crop yield productivity. The experiments were carried out in clay soil during four successive seasons in private farm at Abo-Dawood village, Dakahlia governorate. The experimental field located far from contamination sources such as roads, factories or large cities. The obtained results indicated that the conservation tillage system increased the crop yield about 50\%, 37.5\% in second season and $44.4 \%$, $39.3 \%$ in fourth season in comparison with conventional and intensive tillage systems respectively. addition of Bucills megaterium led to an increase in the wheat crop yield in all tillage treatments with an increase by $20.4 \%, 18.6 \%$ and $19.8 \%$ as well as adding Cyan bacteria led to an increase in the productivity of the wheat crop with an increase by $12.3 \%$, $10.9 \%$ and $7.8 \%$ in conventional, intensive and conservation tillage treatment respectively.

\section{INTRODUCTION}

7 illage techniques affect incorporation of plant residues with soil, consequently, decomposition rate, organic matter and PH. This

gives rise to change in bioavailability of several elements in root biomass distribution.

Davis et al., 1995, found that no-tillage resulted increase in $(\mathrm{P})$ at the $0-5$ $\mathrm{cm}$ depth relative to $(\mathrm{P})$ at the $5-10 \mathrm{~cm}$ depth, and at $0-5 \mathrm{~cm}(\mathrm{P})$ was $35 \%$ greater under no-tillage than under tillage.

Lavado et al., 1999, reported that the conventional tillage reduced the organic mater in soil in comparison with no tillage.

\footnotetext{
* Prof. Dr., Agric. Eng. Dep., Fac. of Agric., Mansoura Univ., Egypt. ** Lecturer of Agric. Eng. Dept., Fac. of Agric., Mansoura Univ., Egypt. ** Eng. in Agric. Eng. Res. Inst. (AEnRI), Giza
} 
The effect of the conventional tillage and zero tillage on concentration and stratification of trace elements demonstrated that copper and nickel didn't show significant differences related to tillage systems. Meanwhile copper (max value $1.46 \mathrm{mg} / \mathrm{kg}$ ) and nickel (max. value $0.65 \mathrm{mg} / \mathrm{kg}$ ) were higher under conventional tillage, while zinc (max. value $2.03 \mathrm{mg} / \mathrm{kg}$ ) and lead (max. value $0.94 \mathrm{mg} / \mathrm{kg}$ ) were higher concentration under zero tillage on top soil $(0-5 \mathrm{~cm})$ but from 5 to $25 \mathrm{~cm}$ depth the concentration was significantly higher under conventional tillage. Green et al., 2007, reported that the no-tillage system resulted in greater biological activity than disk harrow and disk plow in the $0-5 \mathrm{~cm}$ depth due to crop residues accumulation on the soil surface under no tillage.

Santiago et al., 2008, found that no tillage and minimum tillage systems led to heavy metals accumulation in the surface layer of soil. DTPA extractable $\mathrm{Cu}$ and $\mathrm{Zn}$, were higher under no tillage $(2 \mathrm{mg} / \mathrm{kg}, 0.5 \mathrm{mg} / \mathrm{kg})$ than under conventional tillage $(1.5 \mathrm{mg} / \mathrm{kg}, 0.1 \mathrm{mg} / \mathrm{kg})$ and minimum tillage $(1.7 \mathrm{mg} / \mathrm{kg}, 0.2 \mathrm{mg} / \mathrm{kg})$ respectively. Soil microorganisms affect soil quality and productivity through degradation plants and animals residues, participation in biogeochemical nutrients cycle including addition some nutrient elements to be available for plants in the soil or remediation heavy metals and other pollutants from soil environment. They added that the reduced tillage practices had a better effect on biological soil properties, as microbial activity (which was estimated by B-glucosidase method) of the soil surface $(0-5 \mathrm{~cm}$ layer) was found to be significantly higher under no-tillage $\left(47 \mu \mathrm{g}\right.$ Para Nitro Phenol $\left.\mathrm{g}^{-1} \mathrm{~h}^{-1}\right)$ than under conventional tillage ( $23 \mu \mathrm{g}$ Para Nitro Phenol $\mathrm{g}^{-1} \mathrm{~h}^{-1}$ ) or minimum tillage (36 $\mu$ g Para Nitro Phenol g ${ }^{-1} h^{-1}$ ).

Khider, 2010, reported that the conservation tillage system (Chisel plow once followed by rotary tiller) increasing the wheat crop yield about $10.1 \%$ and $5.1 \%$ in comparison with the conventional tillage system (Chisel plow twice followed by hydraulic leveller) and intensive tillage system (Moldboard plow once followed by rotary tiller). 
The aim of this study is to investigate the influence of adding different soil microorganisms under different tillage systems \{Conventional $\left(\mathrm{Ch}_{2}+\mathrm{L}\right)$ Intensive $\left(\mathrm{Ch}_{2}+\mathrm{R}\right)$ and Conservation $(\mathrm{Ch}+\mathrm{R})$ tillage $\}$ on concentration of some heavy metals and productivity of crop yield.

\section{MATERIALS AND METHODS}

The experiments were carried out in clay soil (54.5\% clay, $29.2 \%$ silt and $16.3 \%$ sand) during four successive seasons (from May 2009 to April 2011) in private farm at Abo Dawood village, Dakahlia governorate. The experimental field located far from contamination sources such as roads, factories or large cities. The experimental area was about 0.5 feddan. According to seed bed preparation systems, the experimental area divided into three parts, each part about $700 \mathrm{~m}^{2}$ (net dimension of $14 \times 48$ $\mathrm{m})$.

1- Conventional tillage $\left(\mathbf{C h}_{2}+\mathbf{L}\right)$ : Two passes chiseling followed by wooden land leveler.

2- Intensive tillage $\left(\mathbf{C h}_{2}+\mathbf{R}\right)$ : Two passes chiseling followed by rotary tiller.

3-Conservation tillage $(\mathbf{C h}+\mathbf{R})$ : One pass, chiseling followed by rotary tiller).

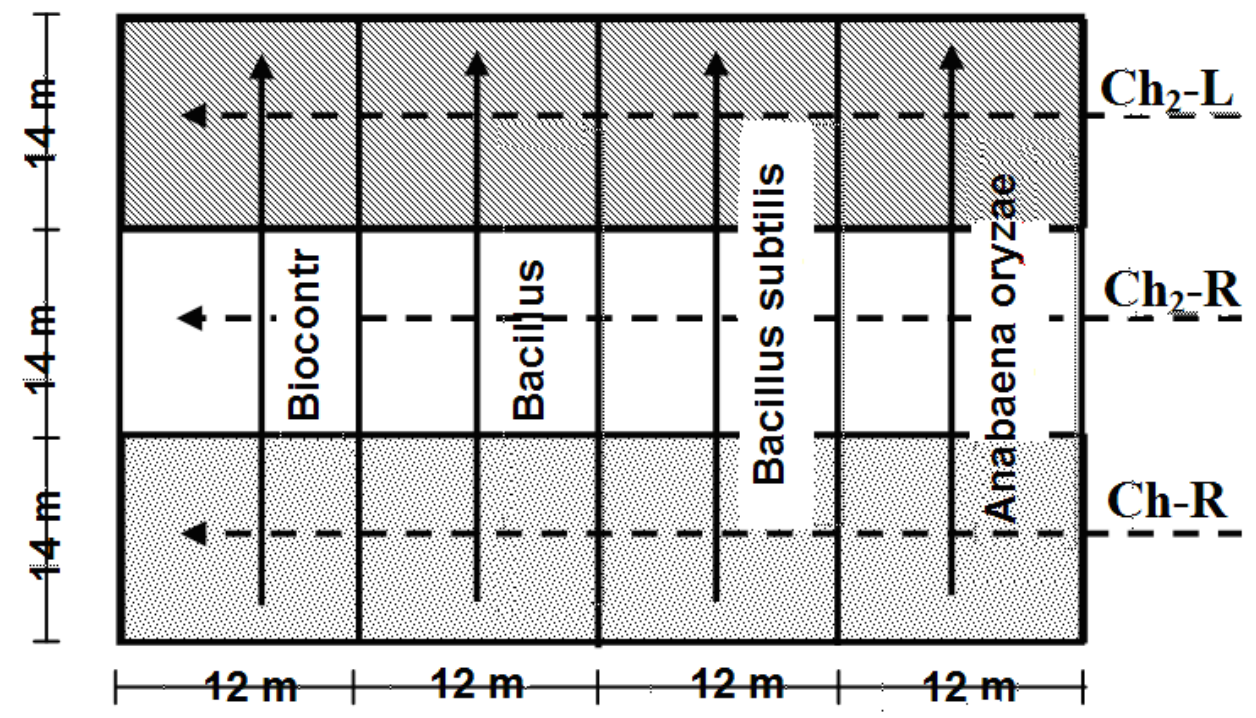

Fig. 1: Experimental field layout. 
In the fourth season, each part was divided into four subplots, in according with adding of microorganisms (Fig. 1), which are:

1- Biocontrol Treatment: Without adding any Microorganisms

2- Bacillus megatherium var. phosphaticum ( B. meg.)

3- Bacillus subtilis (B. subt.)

4- Anabaena oryzae 231 (Cyan B.)

The concentration of available heavy metals Lead, Nickel, Zinc and Copper were determined in both surface $(0-10 \mathrm{~cm})$ and bottom $(10-20$ $\mathrm{cm})$ layers. The available heavy metals was extracted by Ethylene Diamine Tetra-acetic Acid (EDTA), according to Cottenie et al., 1982, Analyses were carried out in Soil Sci. Dept. Fac. of Agric., Kafer ElSheikh Univ.

Plate count technique was used to determine total bacterial count using soil extract agar media (Allen, 1959). Total count of bacterial was carried out in Microbiology Dept., Fac. of Agric., Mansoura Univ.

The crop yield was evaluated by taking five randomly selected samples of one square meter area for each plot. The yield was expressed as dry matter weights. The samples were collected using a wooden frame (1 $\mathrm{m}^{2}$ ), which was placed on the field carefully with a randomize way in each plot. Five samples were taken and shelled by hand and weighed and used to extrapolate the crop yield per feddan.

\section{RESULTS AND DISCUSSIONS}

\section{Tillage systems via concentration of available heavy elements}

The results indicated that all the seedbed preparation systems, which used in this study, reduced the concentration of tested available elements.

Fig. 2 shows the concentration of available heavy metals ( lead, Nickel, Zinc and Copper) before tillage treatments in surface layer $(0-10 \mathrm{~cm})$ are higher than in bottom layer $(10-20 \mathrm{~cm})$ by about $24.77 \%, 10.57 \%$, $19.72 \%$ and $12.91 \%$ respectively. Using conservation tillage system (ChR) decreased the concentration of available lead, Nickel, Zinc and 
Copper elements about $21.7 \%$ and $47 \%, 25.2 \%$ and $9.7 \%, 35.3 \%$ and $50.8 \%, 9.3 \%$ and $4 \%$ in surface $(0-10 \mathrm{~cm})$ and bottom layer $(10-20 \mathrm{~cm})$ in comparison with before tillage respectively. The results indicated that the conservation tillage system has a clear impact in reducing the proportion of elements in the soil compared to other tillage systems. Also, the results showed a significant decrease of the various elements in all depths, except for the lead in the surface layer, which achieved the highest decrease of available element concentration in the surface layer after using intensive tillage system for other systems.
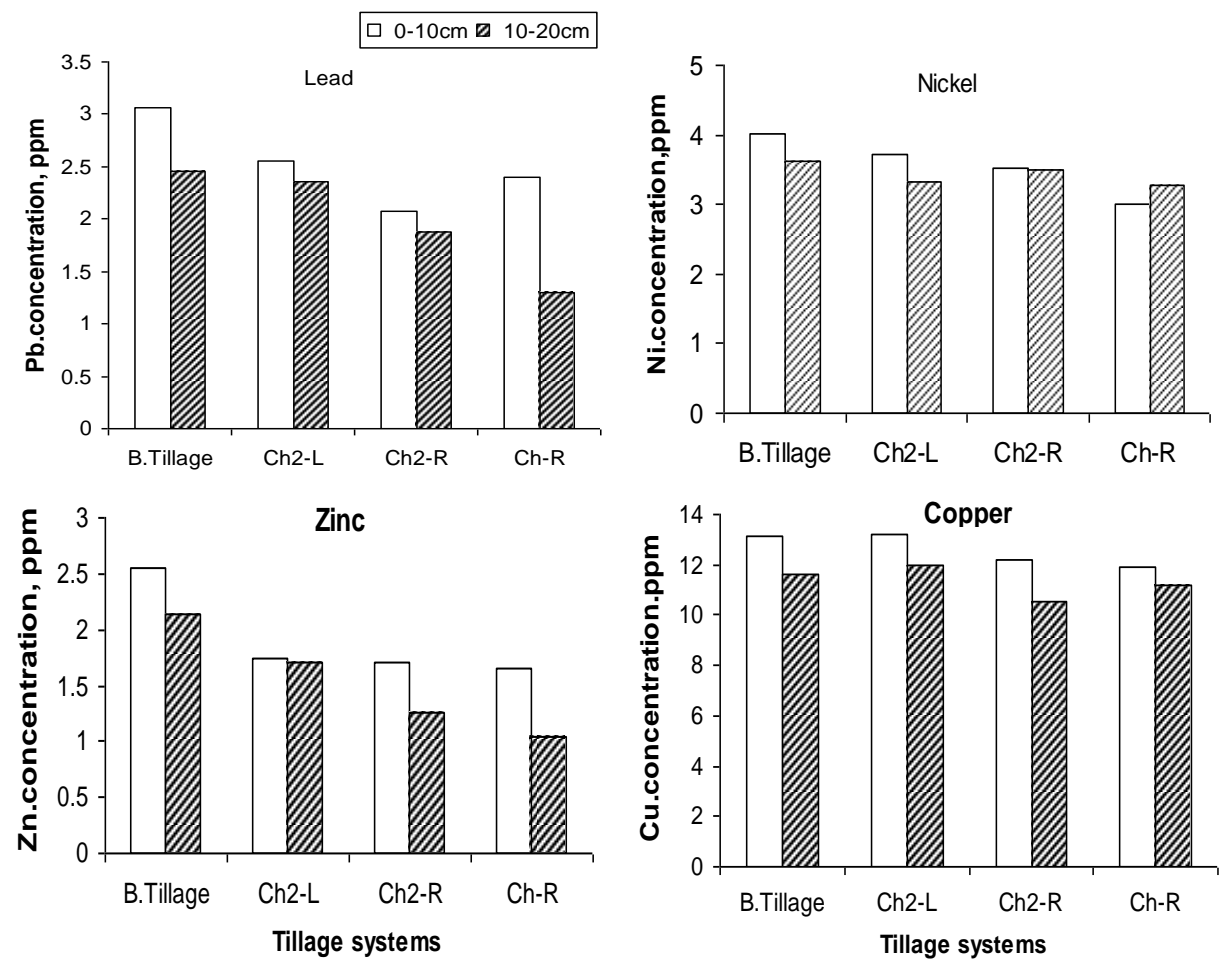

Fig. 2: Effect of tillage systems on available heavy metals concentration Adding soil microbes via concentration of available heavy metals

The effect of adding soil microbes on concentration of available heavy metals in soil was illustrated in Fig. 3. Adding Bacillus megaterium to soil achieved a reduction in the proportion of available lead element for the conventional tillage treatment by $54 \%, 18 \%$ at depths of $0-10$ and $10-$ $20 \mathrm{~cm}$ and about $47.9 \%$ at soil depth of $0-10 \mathrm{~cm}$ for conservation tillage 
treatment. Whereas, adding Bacillus subtilis reduced the concentration of available lead element by about $24.4 \%$ at soil depth of $0-10 \mathrm{~cm}$ for intensive tillage treatment and 41.5\%, 29.9\% for conservation tillage treatment at the depths of 0-10 and10-20 cm respectively (Fig 3-A).

Fig 3-B showed that, adding Bacillus megaterium decreased the concentration of available nickel element by about $16 \%, 23 \%$ for conventional tillage treatment at the depths of $0-10$ and10-20 cm respectively. Whereas, by adding Bacillus subtilis reduced the concentration of available nickel element about 17\%, 14\% and 16.7\%, 16\% at soil depth of $0-10$ and $10-20 \mathrm{~cm}$ for intensive tillage and conservation tillage treatments respectively.

Fig 3-C showed that adding Bacillus megaterium decreased the concentration of available zinc element about by $17.2 \%, 20 \%$ for conventional tillage treatment at depths of $0-10$ and10-20 cm respectively. Whereas, by adding Bacillus subtilis reducing the concentration of available zinc element about $23.6 \%, 24 \%$ at soil depth of 0-10 and 10-20 cm for intensive tillage treatment respectively. While conservation tillage treatment was affected by adding Bacillus megaterium and Bacillus subtilis, whereas the concentration of available zinc element decreased about $32.7 \%, 25.9 \%$ and $36.7 \%$ and $33.3 \%$ at soil depth of 0-10 and 10-20 cm respectively.

\section{Under different tillage system}

Fig 3-D showed that adding B. meg decreased the concentration of available copper element about $22 \%$ for the conventional tillage treatment at the depths of $0-10 \mathrm{~cm}$. Whereas, by adding Bacillus subtilis reduced the concentration of available copper element about $22.5 \%$, $20.8 \%$ at soil depth of $0-10$ and $10-20 \mathrm{~cm}$ for intensive tillage treatment respectively. While conservation tillage treatment affected by adding of Bacillus megaterium and Bacillus Subtilis. Whereas, the concentration of available copper element decreased about 24\%, 29\% and $25.9 \%$ and $27.7 \%$ at soil depth $0-10$ and $10-20 \mathrm{~cm}$ respectively. 

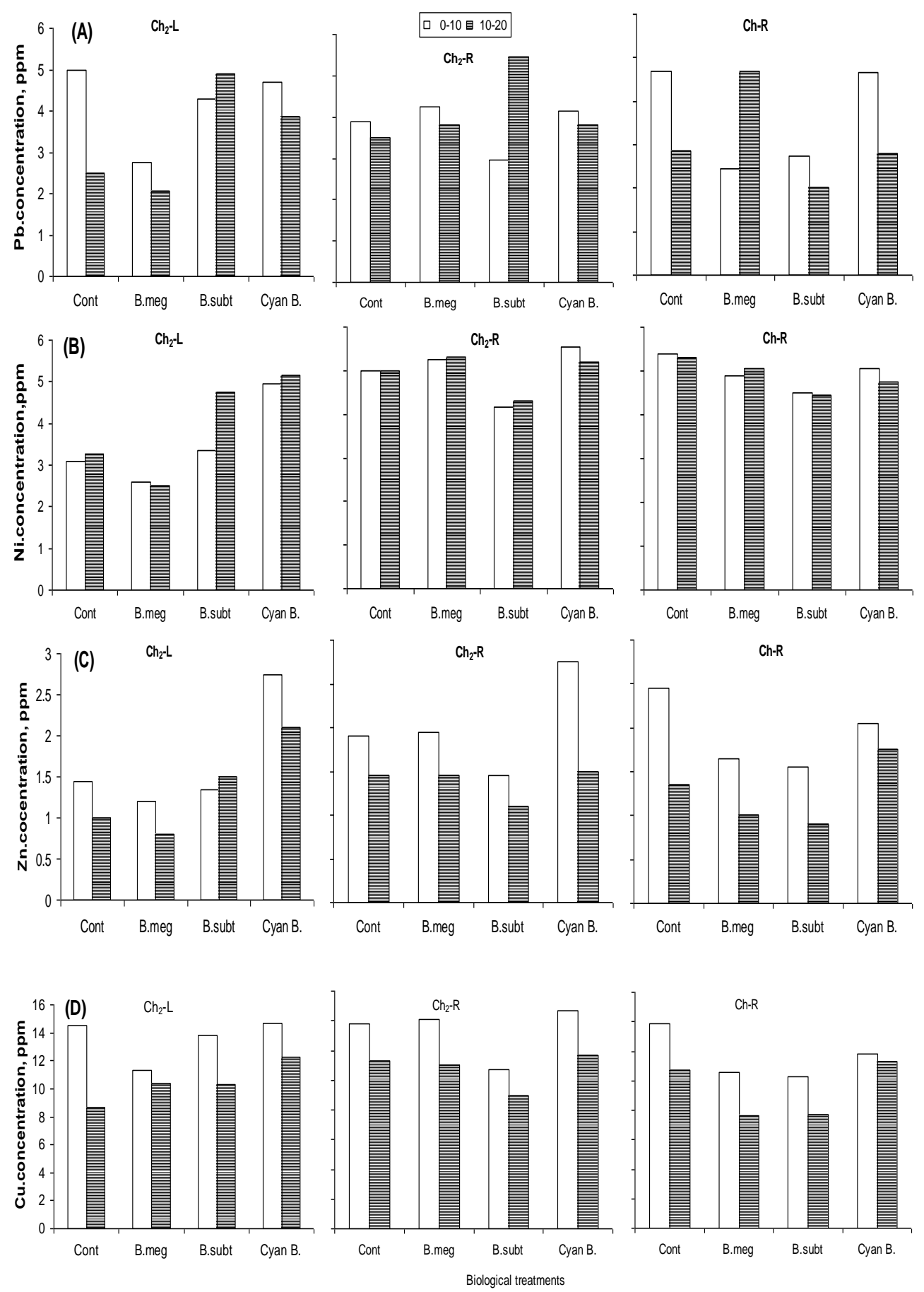

Fig. 3: Effect of adding soil microbes on concentration of available heavy metals. 


\section{Tillage systems and soil microbes via wheat yield}

The obtained results in figure (4) showed that the conservation tillage system recorded the highest crop yield in comparison with conventional and intensive tillage systems. Conservation tillage treatment recorded increase of wheat crop yield by about $44.4 \%, 39.3 \%$ more than conventional and intensive tillage treatments.

Adding different types of bacteria led to increased crop productivity in all tillage treatments. Bucills megaterium recorded an increase of wheat crop yield for all tillage treatments by $20.4 \%, 18.6 \%$ and $19.8 \%$ as well as adding Cyan bacteria led to an increase wheat crop productivity by $12.3 \%, 10.9 \%$ and $7.8 \%$ in conventional, intensive and conservation tillage treatment respectively. While, the adding Bucillus subtitlus recorded an increase wheat crop yield for intensive and conservation tillage treatments about $16.5 \%$ and $10.9 \%$ respectively. While, adding Bucillus subtitlus have not significant effect on the productivity of wheat crop yield for conventional tillage treatment.

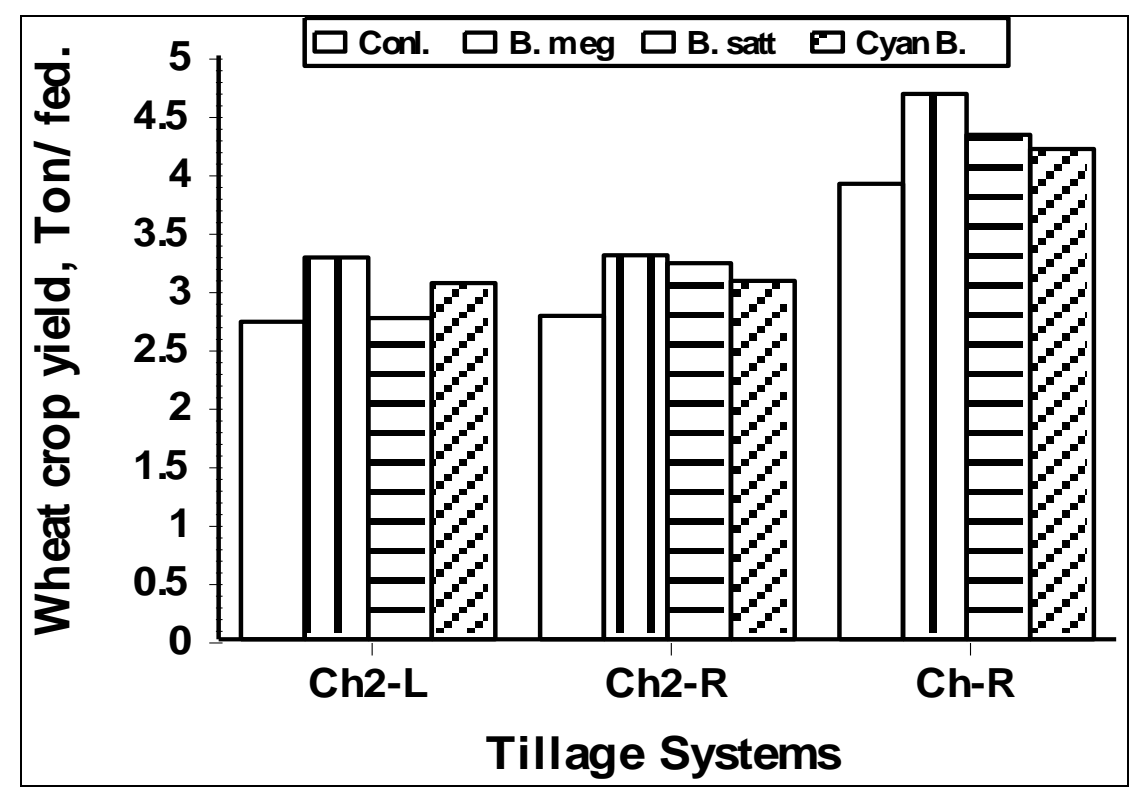

Fig. 4: Effect of tillage systems and soil microbes on wheat crop yield 


\section{REFERENCES}

Allen, O.N. 1959:"Experiments in soil Bacteriology. Burgess Publ. Co. Minne-apolis 15 Minnesota U.S.A.

Cottenie. A; Voloo, M., Kiekeno, L. and Velghe, G.,1982:"Biological and analytical aspects of soil pollution" Labo. of Analytial and agro. state univ. Ghent_belguim.

Davis. J. G.; Weeks. G. and M. B. Parker., 1995: Use of deep tillage and liming to reduce zinc toxicity in peanuts grown on flue dust contaminated land" Soil Technology 8, 85-95.

Green V.S.; Stott .D.E; Cruz J.C and N. Curi, 2007:"Tillage impacts on soil biological activity and aggregation in a Brazilian Cerrado Oxisol" Soil \& Tillage Res. 92, 114-121.

Khider, M. O., 2010:"Development of adding machine unit for microbial materials to maximize utilization from rice straw". Ph. D. thesis, Agric. Eng. Dept. Fac. of Agric., Mansoura Univ.

Lavado, R. S.; Porcelli, C. A. and R. Alvarez, 1999:"concentration and distribution of extractable elements in a soil as affected by tillage and fertilization" Sci. Total Environ. 232, 185-191.

Santiago, A.; Quintero. J. M. and A. Delgado, 2008:"Long-term effects of tillage on the availability of iron, copper, manganese, and zinc in a Spanish Vertisol" Science direct, Soil \& Tillage Res.98, 200-207.

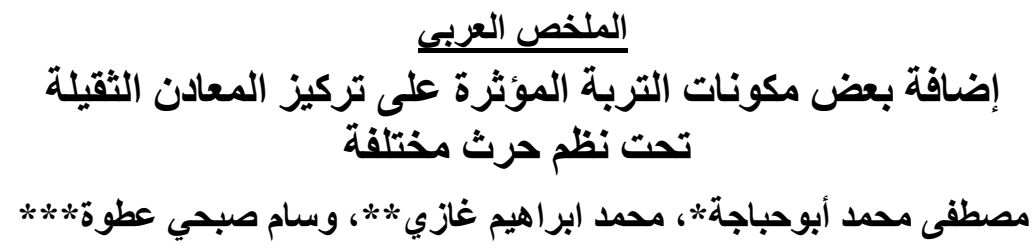

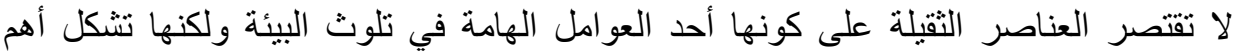

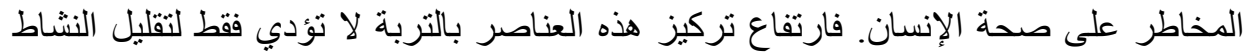

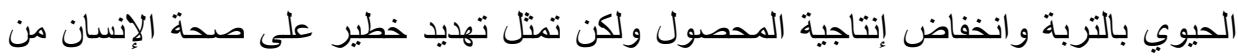

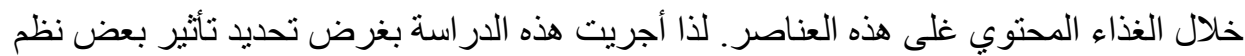
الحرث و إضافة بعض ميكروبات التربة على تركيز بعض العناصر الثقبلة بالتربة.

* أستاذ الهنسة الزراعية المتقرغ بقسم الهندسة الزراعيةـ كلية الزراعةـ جامعة المنصورة ـ مصر.

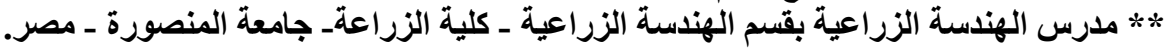

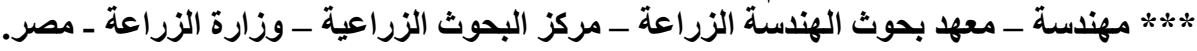




\section{تم التوصل لمجموعة من النتائج يمكن تلخيصها فيما يلي:}

ـ استخدام نظام الحرث لحماية التربة (Ch-R) حقق انخفاض في تركيز العناصـر الثقيلة محل فئل الدر اسة في طبقتي التربة ( • - • (سم)، ( • ـ ـ بسم) بالمقارنة بنظم الحرث الأخرى.

- إضـافة (B.subt., B.meg) حقق انخفاض ملحوظ في تركيز جميع عناصر الدر اسـة في

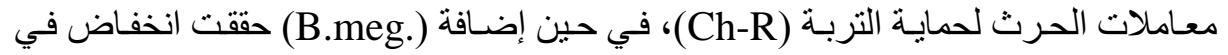

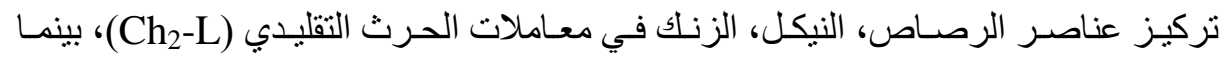
إضافة (B.subt.) حققت انخفاض في تركيز عنصر الزنك في معاملة الحرث الكثيف (Rh2

ـ حققت معاملـة الحـرث لحمايـة التربـة (Ch-R) أعلى انتاجيـة للمحصـول بالنسبـة لمعـاملات

$$
\text { الحرث الآخري. }
$$

- إضافة ميكروبات التربة أدت لزيـادة انتاجيـة المحصول مع جميع معاملات الحرث المختلفة.

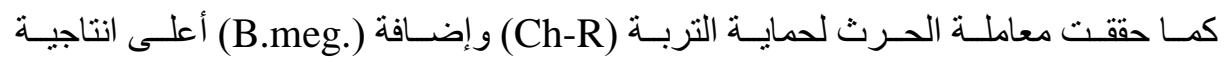
للمحصول بالنسبة للمعاملات المختلفة الآخرى. 